\title{
The Impact of Minister of Marine Affairs and Fisheries Regulation Number 12 of 2020 on the Sustainability of Lobster in Indonesia
}

\author{
Tayibnapis, A. Z., Wuryaningsih, L. E., \& Gora, R. (2020). The Impact of Minister of Marine Affairs and
} Fisheries Regulation Number 12 of 2020 on the Sustainability of Lobster in Indonesia. International Journal of Multicultural and Multireligious Understanding, 7(9), 130-136. Doi: http://dx.doi.org/10.18415/ijmmu.v7i9.1931

Indonesia dikenal sebagai negara kepulauan yang memiliki sumber daya laut melimpah dan selalu menjadi target nelayan dari berbagai negara yang dilengkapi dengan alat pancing modern, sementara nelayan domestik masih dihadapkan pada sejumlah pembatasan terkait penggunaan alat pancing. Hal ini membuat pemerintah, melalui Kementerian Kelautan perikanan, membentuk kebijakan baru yaitu Peraturan Menteri Kelautan dan Perikanan Nomor 12 Tahun 2020 tentang Pengelolaan Lobster dan Kepiting di Wilayah Negara Kesatuan Republik Indonesia yang memperbolehkan penggunaan alat tangkap yang pada kebijakan sebelumnya dilarang untuk digunakan. Kebijakan baru ini merupakan respon dari peningkatan permintaan di pasar internasional. Pemerintah beranggapan bahwa kebijakan yang baru ini dapat membantu nelayan kecil yang kehilangan mata pencaharian akibat kebijakan sebelumnya. Selain itu, legalisasi ekspor benih lobster juga diharapkan dapat memberikan nilai ekonomi pada nelayan dan pembudidaya, eksportir mendapatkan keuntungan, pendapatan negara naik, penyeludupan lobster berkurang, dan ribuan nelayan yang menangkap benih lobster akan diuntungkan.

Namun berlawanan dengan pemerintah, masyarakat beranggapan bahwa Pemberlakuan Kebijakan baru Menteri Kelautan ini justru membawa dampak negatif pada keberlanjutan lobster di Indonesia. Kebijakan ini dinilai lebih menguntungkan investor dibanding dengan nelayan dan pembudidaya lokal. Hal ini dikarenakan harga benih lobster yang menjadi naik sebesar 140\% dan diperkirakan pada tahun keempat pembudidaya tidak lagi mendapatkan benih lobster akibat ekspor yang tidak terkendali. Karena harga meningkat, pembudidaya tidak dapat membeli benih seperti biasanya untuk keberlangsungan usaha. Selain itu, eksportir juga akan lebih memilih mengekspor daripada memasarkannya pada pembudidaya.

Seperti yang kita tahu, Lobster sendiri memiliki potensi besar dalam pasar ekspor Indonesia. Pembudidayaan lobster terus dikembangkan untuk mendapatkan izin ekspor serta memperbanyak kuantitas ekspor lobster. Namun perlu kita ingat juga bahwa lobster merupakan 
sumber daya alam yang jumlahnya terbatas jika dibandingkan dengan tingkat konsumsi yang cenderung terus meningkat. Sehingga untuk menghindari adanya kegagalan dan eksploitasi, produksi lobster harus diturunkan ke titik manfaat netto optimal dengan ketentuan pengenaan pajak yang sama dengan biaya kerusakan lingkungan laut yang telah terjadi. Selain itu, pihak eksportir juga wajib melakukan budidaya lobster di dalam negeri dengan melibatkan pembudidaya lokal. Untuk kedepannya, masyarakat berharap pemerintah dapat membuat regulasi untuk melindungi nelayan dari permainan eksportir dan juga terus memperhatikan keberlanjutan lingkungan bagi budidaya lobster itu sendiri.

Nama: Stefanny Magdalena Susanto

NRP: 130119012 